\title{
超巨大地震発生前後の顕著な地震活動
}

\author{
北海道大学大学院理学研究院自然史科学部門* 小山順二・都 筑 基 博
}

\section{Activity of Significant Earthquakes before and after Megathrust Earthquakes in the World}

\author{
Junji Koyama and Motohiro Tsuzuki \\ Division of Natural History Sciences, Graduate School of Science, Hokkaido University \\ North 10, West 8, Kita-ku Sapporo, 060-0810, Japan \\ E-mail: koyama@mail.sci.hokudai.ac.jp
}

(Received November 15, 2012; Accepted December 29, 2013)

\begin{abstract}
After the 2011 Tohoku-oki megathrust earthquake of $M_{\mathrm{w}} 9.0$, we observed tens of thousands of inland and volcanic earthquakes all over the Japan Islands, which are not confined within the aftershock area of off the Pacific coast of Tohoku region. This reminds us to evaluate the earthquake activity in a much wider sense, discarding an ordinary idea of the foreshock-mainshock-aftershock activity within a limited aftershock area of a particular earthquake. There occurred several megathrust earthquakes worldwide in the last one hundred years. We have studied their significant events before and after the earthquakes based on our new hypothesis on the earthquake generating zone with the distinct difference between Along-dip Double Segmentation (ADDS) and Along-strike Single Segmentation (ASSS). In summary, some of significant aftershocks (larger than $M_{\mathrm{w}} 7.5$ ) of ADDS megathrusts are those (Type I) in and near outer-rises, where some are dip-slip normal faultings and some are strike-slip faultings within subducting oceanic plates with component of normal fault. These outer-rise earthquakes are considered to be controlled by the slab-pull of descending slabs of oceanic plates induced by the reduction of plate couplings by megathrusts. In addition, some are also significant (Type II) along the plate interfaces within aftershock areas and those extending aftershock areas similarly to the corresponding megathrusts. On the other hand, aftershocks of ASSS occurred in and near corresponding aftershock areas and significant and or disastrous outer-rise events are rare. Some large (not significant) inland earthquakes are also known for both ADDS and ASSS megathrusts. All these results are not dependent on whether the subduction geometry is oblique or orthogonal.
\end{abstract}

Key words: Megathrust earthquake, Along-dip Double Segmentaion, Along-strike Single Segmentation, Significant aftershock, Outer-rise earthquake

\section{§1. はじめに}

科学の進歩はその根底にある考えや仮説が検証される ことにある[ポアンカレ (1959)]. 将来の地震観測研究 計画も同じである，我々は超巨大地震が発生する場に，

Along-dip Double Segmentation (ADDS) と Along-strike Single Segmentation (ASSS) という2つの異なる性質が あると考えている [Yomogida et al. (2011), Koyama et al. (2012), 小山・都筑 (2013)].

従来, 大きな地震活動は, 個々の地震セグメントや隣 り合う地震セグメントを含む領域で前震・本震・余震の

* =060-0810 札幌市北区北 10 条西 8 丁目
活動として評価されてきた [例えば，宇津 (2001)]。ま た, 地震観測網の整備・地震発生過程の研究の進歩によ り, 余震活動は, 本震時の断層破壞による局所的な応力 集中を緩和するように, 断層面上や断層周辺部に発生す る [例えば, Yagi et al. (2004)］と考えてきた. 特に, Gutenberg-Richter 則や大森の式 [宇津 (2001)] などよ り, 大きな地震後に起こる顕著な余震の発生は, このよ うな緩和過程の考えのもとに, 確率的な予測が可能に なった，とまで考えられてきた [地震調查研究推進本部 (1988)].

しかし，2011 年 3 月 11 日東北沖超巨大地震は, 東北 沖太平洋側のほとんどすべての地震セグメントを破壊 
し，日本全国で内陸や火山性の地震活動をいたるところ で活性化させた［国土地理院 (2012)]。このような広域 での地震活動は確率的にも, 経験的にも評価できなかっ たことである。 2011 年東北沖超巨大地震が示している ことは, 従来の個々の狭い地震セグメント内の地震活動 で前震・本震・余震といった時系列を考えるのではなく， 超巨大地震を時間基点として，それ以前・以後にどのよ うな顕著な広域の地震活動が発生したかを考慮しなけれ ばならないこと，また震源域から遠く離れた広域な場で 多くの誘発地震を励起することである.

さて，Fig. 1 を見ればわかるように，今回の東北沖超 巨大地震では，太平洋プレートが沈み込む方向に 2 重の 带状の地震セグメント (ADDS) が島弧沿いと海溝沿い の間に 2 重の带状に並んで存在している地域に発生し た。それと比べて, 南海トラフ沿いの南海道・東南海 道・東海地域では，海溝から島弧に至る地域が地震空白 域 (Seismic gap) として沈み込み帯に沿い地震セグメン トが一列の带状に隣り合って並んでいる (ASSS). 我々 が唱えている超巨大地震の発生場の ADDS と ASSS と
は，このような地震活動の地域性をさす．

このような海溝沿いに沈み込む方向に向かい 1 重, 2 重の帯状の地震活動帯が存在するのは日本付近にかぎっ た現象ではなく, 1952 年カムチャッカ地震・1964 年アラ スカ地震は ADDS 型, 1960 年や 2010 年チリ地震は ASSS 型の地震であることが指摘されている [Koyama et $a l$. (2012)]. まとめると, ASSS 型の超巨大地震活動で は, 地震活動域は海溝からの沈み込み带の幅が狭く, 地 震セグメントは幅が長さに比べて小さな細長い領域とな る。また，沈み込み带の固着は海溝沿いから沈み込久方 向全体に拡がり, プレート境界全体に地震空白域を形成 する，地震発生時のアスペリティはこの空白域にある固 着域全体にわたる [Moreno et al. (2010)]. 他方, ADDS 型の超巨大地震活動では, 地震活動域の幅と長さの比が $1: 2$ 程度で幅広く, 真に強い固着を示すのは海溝沿いの 地震セグメント帯である。超巨大地震前の地震活動は島 弧や大陸沿いの地震セグメント帯での固着域の破壊が活 発化することによる。しかし，海溝沿いの真に強い固着 の地震セグメント帯が不活発であるから全体的な地震活

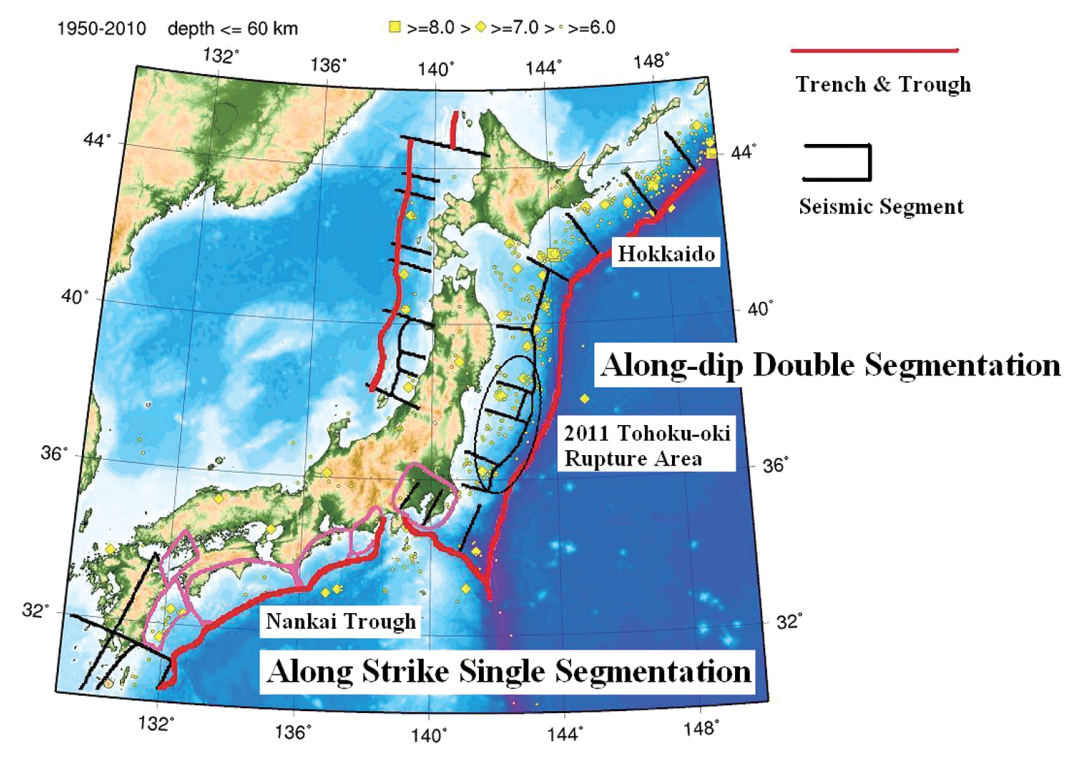

Fig. 1. Seismic activity in Japan and its vicinity. Seismic segmentation is quoted from $<$ http: //www.jishin.go.jp/main/p_hyoka02_kaiko.htm $>$ by the Headquaters for Earthquake Research Promotion. Epicenters of earthquakes are plotted by yellow symbols from 1950 to 2010 with magnitudes determined by Japan Meteorological Agency larger than 5.9 and their focal depths shallower than $61 \mathrm{~km}$. Trench and trough near Japan are illustrated by red curves. Areas surrounded by pinkish curves are the segments where next large earthquakes have been expected. The 2011 Tohoku-oki megathrust earthquake ruptured the area circled by a solid ellipse, where Along-dip Double Segmentation (ADDS, see text) is obvious. Along-strike Single Segmentation (ASSS) can be found in the Nankai Trough, where little recent seismic activity has been observed. Such regions are often called seismic gaps. This figure is reproduced from Figure 1 by Koyama et al. (2012). 
動は海溝沿いの地震活動を欠くドーナッツパターン [Mogi (1969)] のようになる。そして, 真に強い破壊を示 す地震発生時のアスペリティは海溝沿いのセグメントで 限られた範囲である [Ruff and Kanamori (1983), Koketsu et al. (2011)]. この考えは, 最近指摘されている地震活動 に招ける沈み込み带に沿う水平方向の変化 (Alongstrike Variability) [Freymueller et al. (2008), Hariri et al. (2013)] ばかりではなく, プレートが沈み达む方向にも多 様な変化を示すことを示唆している. 同様の主張が, 最 近 Kopp (2013) によって, プレート境界に発達する堆積 層の性質から議論されている。

本研究では比較的近年世界中で発生した超巨大地震発 生前後の顕著な地震 $\left(M_{\mathrm{w}}>7.5\right)$ や被害地震を調べ, 我々 の ADDS/ASSS 仮説を特徴づける地震活動の性質を述 ベる，本研究は，上に述べた空間的特徵ばかりではな く, 地震前後での顕著な地震活動にどのような違いがあ り，そしてその地震活動の違いが ADDS/ASSS の何に 起因するものであるかを考える基礎とすることにある. 将来発生するかもしれない 2011 年東北沖超巨大地震の 大きな余震がどのような性質を示すのかを知り，世界の 超巨大地震がどのような場で発生するかを理解するの は, 地震防災上意義のあることであると考える.

2 重構造となる ADDS 型の地震活動は, 例えば, Heki et al. (1997) が明らかにした東北沖太平洋岸に発生した 地震が引き続き日本海溝の方向へ半年にもわたって断層 すべりが拡大していった事実や，Tanioka et al. (1997) が 海溝沿いの限られた領域で aseismic な振る舞いや津波 地震を励起するのに対して, より深い陸よりの領域で普 通の地震活動が見られる，などとする考えに似てはい る. 数值計算でも, Wang and $\mathrm{Hu}(2006)$ は海溝近くの Outer Wedge (aseismic) とょり深い領域の Inner Wedge (seismic) で応力場が異なるふるまいを示すと指摘して いる. しかし, 東北沖超巨大地震が意味していること は, 従来 aseismic であると考えられ, 非地震的なすべり でひずみを解放していると考えられてきた海溝沿いの領 域でも，大きなひずみの蓄積が存在可能で, 時として超 巨大地震を引き起こす引き金になることである [Tsuzuki and Koyama (2013)]. このように aseismic で安全弁と考 えられてきた海溝に近い領域が大きな歪を蓄積して超巨 大地震に発展するのは, 1964 年アラスカ地震でも同様で ある [Yomogida et al. (2011), Koyama et al. (2012)]. また さらに, 東北沖日本海溝と南海トラフの前弧ウェッジの 構造的な違いも地質学的に指摘されている [岡村 (2012)]. これも我々が提唱している沈み込み带の ADDS/ASSS の違いを反映しているもので，新たな視点で地震活動を 注視しなければならない問題である.

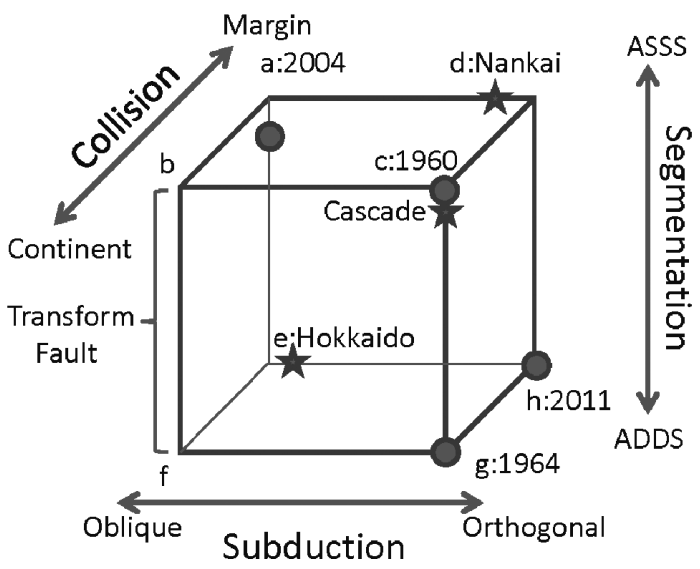

Fig. 2. Variability of megathrust earthquake in the world in terms of seismic segmentations (Alongstrike Single Segmentation, ASSS or Along-dip Double Segmentation, ADDS), subduction zone geometry (orthogonal or oblique collisions) and collisions with continental plate or continental margin (island arc). Typical end-members of great earthquakes are plotted by solid circles with their year of occurrences. Possible future large earthquakes in Hokkaido, Nankai Trough (Fig. 1) and the Cascade subduction zone, Canada are also plotted by stars. This is reproduced from Figure 7 by Koyama et al. (2012).

このような知見は, 具体的には Fig. 2 の星印で示す今 後発生するかもしれない北海道 (ADDS), 南海道やカス ケード・カナダ (ASSS) の地震活動を今後注意深く見守 り, 沈み込久帯の固着の有り様や地震活動の変化を観察 することが急務であることを指し示している.

ここで, 顕著な地震 $\left(M_{\mathrm{w}}>7.5\right)$ に限った理由は, $M_{\mathrm{w}}$ 〜8 を超えるような巨大地震を歴史地震も含めてもれな く評価するために掛けた保険である。 巨大地震は, 単一 のあるいは隣合う地震セグメント内の破壊に複数の小規 模な不均質領域の破壊が伴った複雑な断層破壊と考えら れてきた [Koyama (1997)]. しかし，ここで言う超巨大 地震とは， $M_{\mathrm{W}}$ が 9 程度をこえるような巨大地震を言い， 従来の $M_{\mathrm{w}} \sim 8$ クラスの不均質な地震セグメントの断層 面を複数連動して破壊するような超巨大な地震である. 超巨大地震の震源過程は巨大地震のそれとは不均質領域 の規模が階層構造的に違うものであることを示してい る. 超巨大地震では, 小規模な断層面不均質構造ばかり ではなく，断層破壊域が隣り合う複数の数多くの地震セ グメントに及び，それぞれの地震セグメント $\left(M_{\mathrm{w}} \sim 8\right.$ ク ラスの地震断層）が個性的な断層破壊を示し, 時として 地震発生時に長周期の破壊過程を伴ったりすることもあ 
るからである [Lay et al. (2005), Stein and Okal (2007)].

\section{$\S 2 . \quad$ ADDS (Along-dip Double Segmentation) 型超 巨大地震前後の広域で顕著な地震}

超巨大地震後に発生する顕著な $\left(M_{\mathrm{w}}>7.5\right)$ 地震がどの ような性質かを考えた端緒は Kanamori (1972) の指摘か らである. 1896 年明治三陸津波地震 $\left(M_{\mathrm{t}}^{1)} 8.6\right)$ が東北地 方三陸沖プレート境界で発生し，それによりプレート間 の固着が弱まり，日本海溝近傍のアウターライズで沈み 込む太平洋プレートを断ち切るように 1933 年三陸はる か沖の正断層地震 $\left(M_{\mathrm{w}} 8.4\right)$ が誘発された，とする仮説で ある. 本研究では, このような発生順, 発生場所とメカ ニズムを持つ地震活動をI型の地震活動と呼ぶことにす る。これらの両地震は共に大きな津波を発生させ，三陸 海岸に大規模な被害をもたらした。2011 年東北沖超巨 大地震の最大余震も, 同様に, そのようなアウターライ ズでの正断層型地震が心配されている [Lay et al. (2011)]. アウターライズの地震は発生数も少なく, 今は その前兆を観測したり，東北沖アウターライズ地震の発 生を予測する手段がないので，世界の超巨大地震前後の 大きな地震はどのような性質を持った地震だったのかを 先ず調べてみる.

\section{$2.1 \quad 1964$ 年アラスカ地震}

1964 年 3 月 28 日に発生したアラスカ地震 $M_{\mathrm{w}} 9.2$ は太 平洋プレートがアラスカ半島にほぼ垂直に沈み込む地震 帯で発生したADDS 型地震である [Yomogida et al. (2011), Koyama et al. (2012)]. 地震断層は幅 $300 \mathrm{~km}$, 長 さ $500 \mathrm{~km}$ [Lay et al. (1982)] にもおよんだ。ここでいう プレートが海溝軸に垂直な方向に沈み达むとは，斜め沈 み达み (oblique subduction) の対句として用いている. プレート同士が交差する角度が厳密に 90 度であること を意味している訳ではない. 1964 年アラスカ地震の震 源域近くでは， $M_{\mathrm{w}} 7.0$ をこえる前震活動は USGS の記録 を遡る限りない. 後に述べる 1957 年アンドレアノフ, 1965 年ラット島地震の震源域をのぞくと, アラスカ地震 以後に周辺で発生した大きな地震 $\left(M_{\mathrm{w}} 7.0\right.$ 以上) は, 5 個 存在する。 その内最大と思われるのは 1987 年 11 月 30 日に発生した $M_{\mathrm{w}} 7.8$ の地震である (Fig. 3). この地震は アラスカ海溝のアウターライズというより, 海溝より少 し離れた海側の太平洋プレート内で発生し, メカニズム 解は正断層成分を持つ横ずれ型である。2002 年 11 月 3 日にアラスカ半島内部のデナリ断層沿いに発生したデナ リ地震 $M_{\mathrm{w}} 7.9$ も発生している。したがって,この二つが 1964 年アラスカ地震後に発生した広域に考える震源域 周辺での顕著に大きな地震と考える.

1964 年アラスカ地震の断層すべりからわかる Ten- sion 軸（T 軸）の方向は $\mathrm{N} 24^{\circ} \mathrm{W}$ [Kanamori (1970)] であ る. 当時は観測点の数も少なく, メカニズム解に現在ほ どの決定精度は期待できないが, $\mathrm{T}$ 軸は海溝軸にほぼ直 交する向きに近い. 1987 年の地震メカニズム解 (Fig. 3) は $\mathrm{T}$ 軸が $\mathrm{N} 50^{\circ} \mathrm{W}$ であり, アラスカ地震のすべり方向と 調和的で, 正断層成分をもつ横ずれ型の地震であること がわかる。

この地震が発生した太平洋プレートでは, 南北方向に 並んだ地磁気の縞模様が南東・北西方向に断ち切られる ような破砕帯構造が見られる地域であり [Fowler (2005)], USGS が示す周辺の大きな地震も南北の帯状に 分布している2). このような正断層型の横ずれ地震は, プレート境界での巨大地震の発生でプレート間の固着が 弱くなり, 沈み込んでいるプレートのスラブプル [Kanamori (1972), Christensen and Ruff (1988)] がアウターライ ズ，その海側に地震を引き起こしたと考えられる。しか し, アウターライズに発生する正断層型の地震は, 沈み 込むプレートの曲げによるとする考えもある [例えば, Stauder (1968)].この点は後に再び議論しよう.

また,このような地震については, 超巨大地震の直接 の余震や誘発地震ではなく, 沈み込むプレート内部が分 裂するとする考えもある。この考えは, 次の 2004 年ス マトラ地震の項でもう一度議論する。ここでは, アウ ターライズ周辺の地震メカニズム解はサブダクションプ ルが主たる原因で，横ずれ型 (Strike-slip) になるか, 正 断層型 (Dip-slip) になるかは, 沈み达む海洋プレートが 持つ構造的な性質によるものと考える. 結論として, 地 震の規模から判断して, アラスカ地震後の最大余震とし て挙げられるのは 1987 年のアウターライズの海側の地 震 (I 型) で正断層成分を持つ横ずれ型の地震である. 2002 年デナリ地震は, この地震と同規模の地震で, アラ スカ半島内陸のデナリ大断層沿いで発生した右横ずれ型 の地震である。デナリ断層は, カナダ西端からアラスカ 半島内部にかけ北西方向から西南西方向へ大きく曲がっ ている。この断層は, 東端をカナダ西海岸のクイーン シャーロット右横ずれ断層に画された太平洋プレート西 端部の角の一部がアラスカ半島に沈み込み, 生じたと考 えられている3゙. デナリ地震が, 1964 年アラスカ地震に 誘発された地震か, 周辺のひずみ蓄積によるものか否か

\footnotetext{
1) M:USGS/気象庁による表面波マグニチュード, $M_{\mathrm{w}}$ : USGS によるモーメントマグニチュード $M_{\mathrm{t}}$ : 津波マグニチュード http://earthquake.usgs.gov/earthquakes/world/histo rical_country.php

2) http://pubs.usgs.gov/of/2010/1083/b/

3) http://www.aeic.alaska.edu/html_docs/faq.html
} 


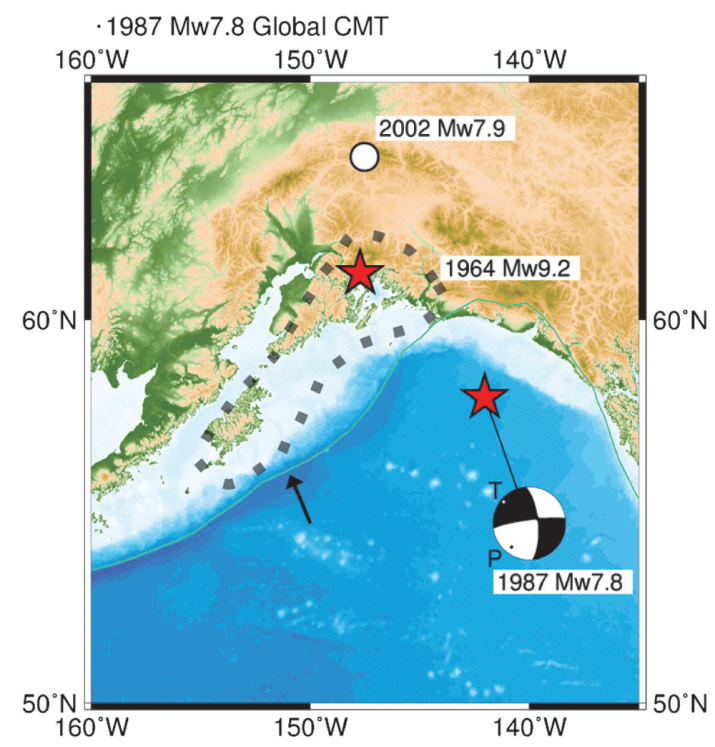

Fig. 3. Epicenters are plotted by stars of the 1964 Alaska megathrust earthquake of $M_{\mathrm{w}} 9.2$ and the 1987 outer-rise earthquake of $M_{\mathrm{w}} 7.8$ off shore Alaska and the 2002 Denali earthquake of $M_{\mathrm{w}} 7.9$ by open circle. Global CMT solution of the 1987 event is illustrated on the lower hemisphere. The solution is from <http://earthquake.usgs.gov/ earthquakes/world/historical_country.php $>$. Dark and white portions of the focal mechanism beachball indicate tensional $(\mathrm{T})$ and compressional $(\mathrm{P})$ regions of $\mathrm{P}$-wave initial motions. Thick broken curve surrounds the aftershock area of the 1964 event. Arrow indicates the motion direction of the Pacific plate along the longitude of $150^{\circ} \mathrm{W}$, where the direction varies from due NNW at the QueenCharlotte portion of Western Canada to almost due West at the Aleutian $\mathrm{Arc}^{3)}$.

は, この地震が 1964 年アラスカ地震から離れた広域で 発生し周辺の地殼構造が複雑に入り組んでいる大陸内の 地震であるから，断定することはできない．

\subsection{4 年スマトラ地震}

2004 年 12 月 26 日スマトラ海溝沿いに, スマトラ半島 沖からニコバル・アンダマン諸島にかけて $M_{\mathrm{w}} 9.3$ の超巨 大地震が発生した。この地震による破壊域は震央付近の スマトラ島沖の地震セグメントでは幅 $240 \mathrm{~km}$, 長さ 420 $\mathrm{km}$ 程度の幅広い断層であったが, 破壊が進展したニコ バル・アンダマン諸島付近の地震セグメントでは, 幅 $160 \mathrm{~km}$, 長さが $570 \mathrm{~km}$ であり, 全体の断層破壊は 1300 $\mathrm{km}$ にも及んだ [Lay et al. (2005)]. 2012 年 4 月 11 日 $M_{\mathrm{w}}$ 8.6 の巨大地震がスマトラ島沖のアウターライズの海側 に発生した。 1987 年アラスカ沖地震の場合と同様に, こ

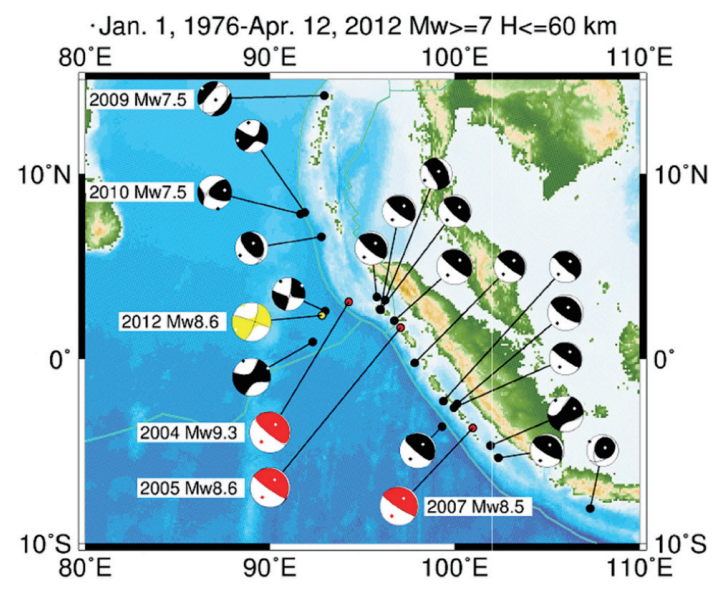

Fig. 4. Large earthquakes from January 1, 1976 to April 12, 2012 along the Sumatra trench are indicated by solid circles, whose moment magnitude $M_{\mathrm{w}}$ is larger than 6.9 and focal depth shallower than $61 \mathrm{~km}$. Significant earthquakes of the 2004 Sumatra earthquake of $M_{\mathrm{w}} 9.3$, the 2005 Nias earthquake of $M_{\mathrm{w}} 8.6$, the 2007 Bengkulu earthquake of $M_{\mathrm{w}} 8.5$ and the latest outer-rise earthquake off shore Sumatra of $M_{\mathrm{w}} 8.6$ of April 11, 2012 are indicated by color. Global CMT solutions are the same as those in Fig. 3.

-Mar. 2011-Apr. 2012 GCMT

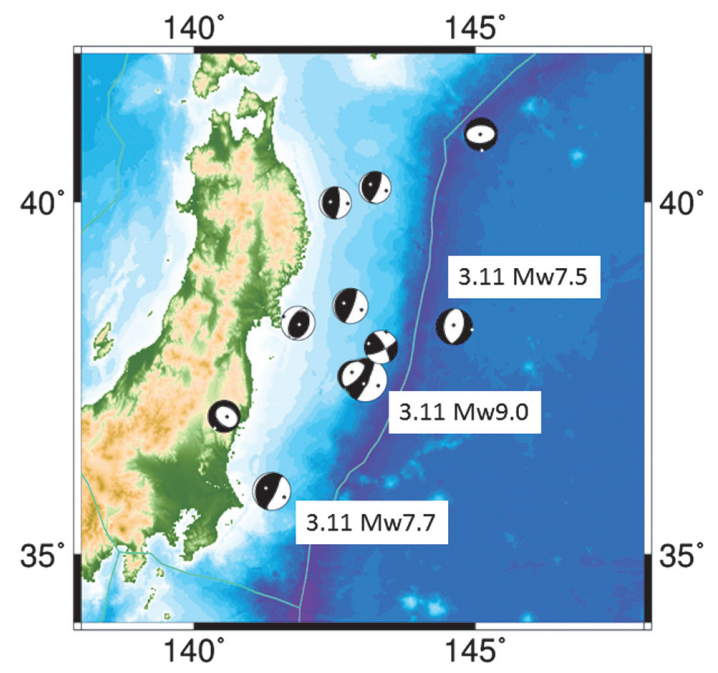

Fig. 5. Large earthquakes after the 2011 Tohokuoki megathrust earthquake are plotted. Two largest aftershocks up to now are indicated. Others are the same as those in Fig. 3. 
の地震も正断層成分を持つアウターライズから少し離れ たインド・オーストラリアプレート内での横ずれ型の地 震である. 現在まで, この地震が 2004 年の震源域南東 に本震破壊方向とは逆方向に震源域を拡大するように発 生した 2005 年 3 月 28 日ニアス島付近で発生した $M_{\mathrm{w}} 8.6$ の地震と共に, 2004 年スマトラ・アンダマン地震後に震 源域周辺で発生した最大規模の地震である (Fig. 4).

2004 年スマトラ・アンダマン地震の震源域における前 震活動は, $M^{1)} 7.0$ をこえるような地震にかぎれば, 1941 年 $M 7.5$ と 2002 年 $M_{\mathrm{w}} 7.3$ の地震が知られているだけで ある，本震以前の小さな地震を含む活動を見れば，初期 破壊のスマトラ島沖の本震震源域近くでは地震活動は活 発で, 断層破壊が進行し最終的に非常に細長い断層を形 成したニコバル・アンダマン諸島周辺では本震以前に地 震活動はほとんどない [Lay et al. (2005)]. 上に述べた が, 本震震源域では断層の幅と長さの比はおおよそ $1: 2$ であるが，ニコバル・アンダマン諸島付近になるとその 比は $1: 3.5$ である. 後者は ASSS 型の地震活動の特徵を 示している.さらに, 本震震源域の南東側で発生した 2005 年ニアス島付近の最大余震は $M_{\mathrm{w}} 8.6$ にしては津波 の励起が小さい.これは同地震の余震活動域を見ればわ かるが, この地震の断層破壊は沈み込み带の深い部分に 拡がっており, 地震による海底地殼変動が小さかったか ら津波の励起が小さかったと考えられる. 谷岡・ Gusman (2012) の Fig. 5 によれば, 1907 年スマトラ地震 [Kanamori et al. (2010)] は 2005 年ニアス島付近の地震の 海溝側に発生した津波地震である。ささらその南東, 2007 年 9 月 12 日ブンクル地震 $\left(M_{\mathrm{w}} 8.4\right)$ とその後近くの 海溝沿いに発生した 2010 年 10 月 25 日メンタワイ津波 地震 $\left(M_{\mathrm{w}} 7.8\right)$ は沈み込みの Dip 方向に隣り合って並ん でいる。これらはすべてこの地域が 2 重セグメントの ADDS 型の地震活動であることを示している。このよ うに, 2004 年スマトラ地震の震源付近のスマトラ島沖の 地震セグメントでは, ADDS 型の地震活動の特徵を示し ていると考えられ，断層破壊が進行したニコバル・アン ダマン諸島付近では ASSS 型の地震活動と理解される. ニコバル・アンダマン諸島周辺では 2004 年スマトラ地 震の大きな余震が 2009 年 8 月 10 日と 2010 年 6 月 12 日 （共に $M_{\mathrm{w}} 7.5 ） に$ 発生しているだけで $M_{\mathrm{w}} 7.6$ 以上の顕著 な地震は発生していない.

インド・オーストラリアプレートが斜めに沈み込んで いるこの地域では, 斜め沈み込みの島弧帯でも海溝軸に ほほ垂直方向に変位する低角の逆断層地震が起こる [Lay et al. (2005), Stein and Okal (2007), 小山・他 (2012)]. 2012 年 4 月の地震は $\mathrm{T}$ 軸がこの 2004 年スマ トラ地震のすべりの方向（北西方向）を向く正断層成分
を持つ横ずれ型のメカニズムである。この周辺は，イン ド・オーストラリアプレート内にほぼ南北に伸びる古い 海嶺が数多く発達している地域であり, 1987 年アラスカ 沖地震と同様に，そこに2004 年の超巨大地震によりプ レート間の固着が解放され, 沈み込んでいるプレートの スラブプルがこのようなメカニズムの地震を発生させた と考えられる。したがって, 2004 年スマトラ地震の 2012 年にアウターライズ周辺に発生した巨大地震は, 1987 年アラスカ沖地震の場合と同様に I 型の地震活動 で, 正断層成分を持つ横ずれ型の地震である.

最近 Yue et al. (2012) や Royer (2012) は 2012 年 4 月の スマトラ半島沖の地震活動はインドプレートとオースト ラリアプレートが持つそれぞれの拡大速度の違いによ り, インド・オーストラリアプレートが分裂を始めた証 拠ではないかと考えている. しかし, 1964 年アラスカ地 震後の地震もこの地震も古い海嶺や破砕帯からなる複雑 な海洋プレート内部での地震活動である. その複雑なプ レート構造がプレートの分裂を示すのか, 複雑な構造が 弱面として地震をその場所に誘発したのかの当否は今後 の議論によるものである. いずれにしても, 超巨大地震 によりスラブプルが沈み込む海洋プレート内の構造に依 存した横ずれ型の地震を発生させたと考える.

2005 年ニアス島地震は, 2004 年スマトラ地震の南東 方向に震源域を直接拡大した最大余震である。このよう な震源域を拡張するような余震活動は従来から知られて おり, ここでは II 型の地震活動と呼ぶことにする.

\subsection{1 年東北沖地震}

太平洋プレートの沈み込みがほぼ垂直に近い沈み达み 带で発生した 2011 年 3 月 11 日東北沖超巨大地震 $M_{\mathrm{w}} 9.0$ は, 東北地方太平洋沖のほとんどの地震セグメントを連 動して破壊し, $200 \mathrm{~km} \times 500 \mathrm{~km}$ 程度の震源域を形成し た. Fig. 1 にも示したが, この地震は典型的な ADDS 型 の地震活動である。現在まで（2012 年 11 月 13 日）のと ころ大きな余震は, 本震当日 3 月 11 日に発生した茨城 県沖の $M_{\mathrm{w}} 7.7$ と宮城県沖のアウターライズに発生した $M_{\mathrm{w}} 7.5$ の余震である. 茨城県沖の余震は余震域を拡大 したような II 型の地震活動である. $M_{\mathrm{w}} 7.5$ の余震のメ カニズム解は正断層型である (Fig. 5). 後者の地震は, メカニズム解, 震源位置共に 1933 年三陸津波地震と地 震発生パターンはよく似ており, 地震規模ははるかに小 さいが, I 型の地震活動である。もちろん 1896 年明治三 陸津波地震は時定数の長いゆっくり地震で [Kanamori (1972)], 今回の 2011 年東北沖地震は断層破壊にゆっく り成分も伴う地震であったかもしれないが [例えば, Koper et al. (2012)], 断層破壊の主要部は海溝沿いの巨 大なアスペリティーである[例えば, Koketsu et al. 


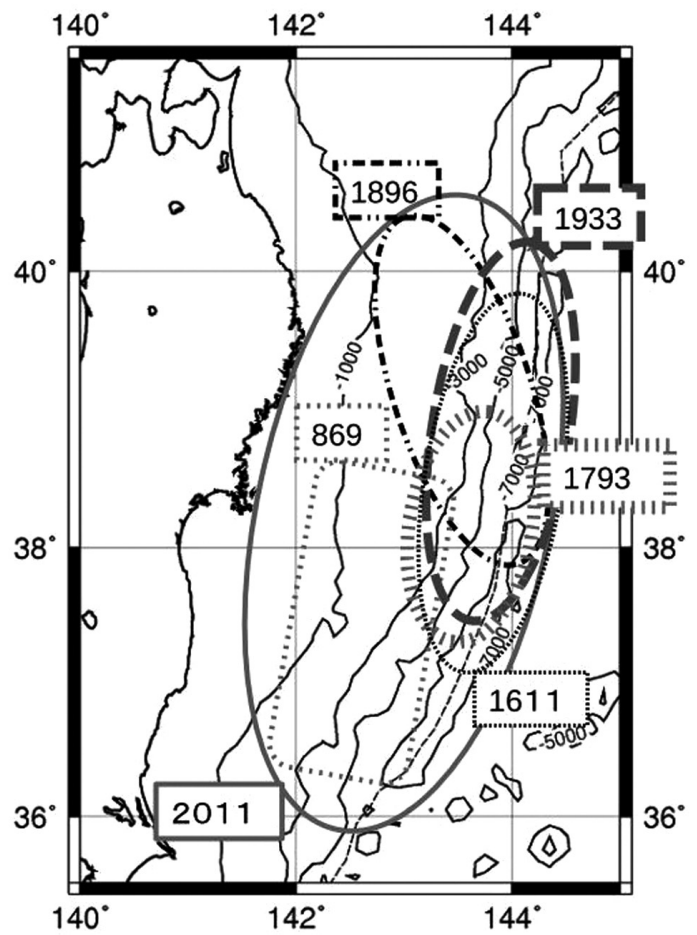

Fig. 6. Rough sketches of tsunami source areas are reproduced with ocean bottom bathymetry in the Tohoku-oki region, Japan. The 2011 Tohoku-oki megathrust earthquake is from Hayashi et al. (2011), the 869 Jyogan tsunami earthquake of $M 8.3$ from Namegaya et al. (2010), the 1611 Keicho earthquake of $M \sim 8.1$, the 1793 Kansei earthquake of M8.0 8.4, the 1896 Meiji Sanriku tsunami earthquake of $M_{\mathrm{t}} 8.6$ and the 1933 Showa Sanriku earthquake of $M_{\mathrm{w}} 8.4$ are from Hatori (2000).

(2011)．このように 1896 年明治三陸津波地震とは発生 様式が異なるように見えるが, 1896 年明治三陸津波地震 よりはるかに地震規模が大きな 2011 年東北沖超巨大地 震の余震としてさらに巨大なアウターライズの正断層型 の地震が発生することを否定することはできない. Kanamori (1972)の指摘が正しいものなら，1964 年アラ スカ地震後の 1987 年アラスカ沖地震を考えて, 今後さ らに 30 年以上にわたり大きな余震を警戒することが必 要である.

三陸沖では 1896 年の津波地震だけではなく, 1793 年 寛政の地震 $(M 8.0 \sim 8.4), 1611$ 年慶長の津波地震 $(M$ ～ 8.1), 869 年貞観地震 (M8.3) が発生し (Fig. 6), 甚大な津 波被害を発生している。しかし, これらの地震では, 顕 著な被害をもたらした大きな余震, アウターライズの余 震，またその余震による津波は今のところ発見されてい
ない. より小さな地震, 付近での小規模な津波は, 歴史 地震でも記載されており [宇佐美・他 (2013), 渡辺 (1998)], 大きな被害を伴った地震や津波は網羅されてい ると考えられる。したがって, 1896 年明治三陸地震後の 1933 年昭和三陸地震はこの地域では特異なアウターラ イズの地震かもしれないが, 2011 年東北沖超巨大地震 は，それらすべてを凌駕するような (Fig. 6) 大きな地震 であるから，その最大余震も十分大きなものであること が考えられる [Lay et al. (2011)]. アウターライズの詳細 な地震活動調査や地殼変動観測で何とかその変動をとら えたいものであるが, 残念なことに, 2011 年地震直後の 余震観測 [Obana et al. (2012)] をのぞき, 地震直後から計 画されていた定常的な海域観測網の整備には, アウター ライズの観測は含まれておらず [日野 (2012)], 重要性が 認識されてなかった。最近の新しい観測計画［防災科学 技術研究所 (2013)］ではこの点も盛り込まれている.

補足だが, 1896 年明治三陸地震では, 2 か月後に陸羽 地震 $M 7.2$ が内陸に発生している. また, II 型の余震活 動として, 1897 年 8 月 5 日 $M 7.7$ の地震が釡石沖に発生 している。 2011 年東北沖超巨大地震の一連の地震活動 を見れば, 2008 年岩手・宮城内陸地震 $M_{\mathrm{w}} 7.2$ が震源域近 くの内陸に発生している. しかし, Fig. 6 にあげた過去 の顕著な地震前後では, 1804 年象潟地震 $(M 7.0)$ のよう に被害地震ではあるが規模はあまり大きくない地震活動 をのぞけば，顕著な内陸での地震活動は記録されていな w.

\subsection{2 年カムチャッカ地震}

1952 年 11 月 4 日カムチャッカ地震 $M_{\mathrm{w}} 8.8$ は周辺で発 生した大きな地震の余震域や, $630 \mathrm{~km} \times 200 \mathrm{~km}$ にも及 ぶ津波の波源域 [Johnson and Satake (1999)] からほぼ垂 直に沈み込む地震带の ADDS 型の地震と考えられる. 1959 年 5 月 4 日に発生した $M_{\mathrm{w}} 8.2$ の地震が本震の震源 域を北東方向に拡大した II 型の最大余震である (Fig. 7). アウターライズの正断層型地震（更に小さな地震は 除く）は 1989 年 4 月 11 日 $M_{\mathrm{W}} 6.7$ だけのようであり, 顕 著なアウターライズ地震 $\left(M_{\mathrm{w}}>7.5\right)$ は発生していない. また, カムチャッカ半島内陸にも顕著な地震は発生して いない. ただ, 1904 年に $M 8.3$ と 8.1 の 2 つの地震が本 震震源域陸側に発生しているだけである.

もし, Stauder (1968) が主張するように, アウターラ イズの正断層型地震が沈み込むプレートの曲げによるも のであるなら, ここでも, アラスカ沖や東北沖と同様に, アウターライズに大きな正断層型地震が期待される。し かし, 1952 年の地震後ここに顕著な正断層型地震は見出 せていない. また, アラスカ地震やスマトラ・アンダマ ン地震の最大余震は, 正断層成分を持つ横ずれ型の地震 


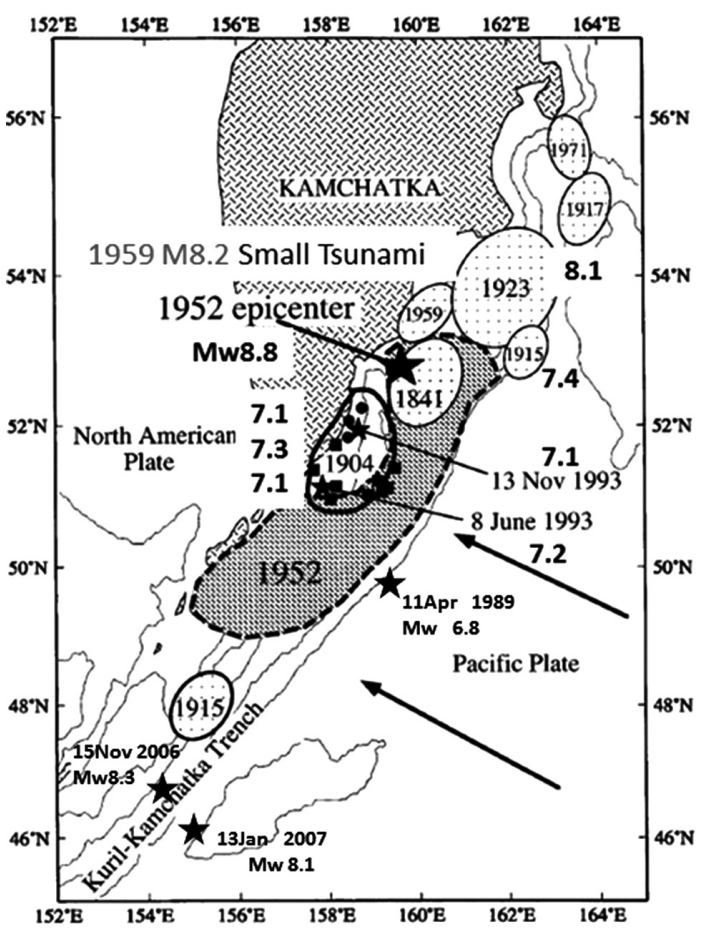

Fig. 7. Activity of large earthquakes near the Kamchatka Peninsula. Surface-wave magnitude $M$ and moment magnitude $M_{\mathrm{w}}$ are indicated. Modified from Fig. 1 of Johnson and Satake (1999).

で，海洋プレートの曲げではそのようなメカニズムの地 震は発生しない. したがって, 小さな地震は別として, Stauder (1968) の主張がアウターライズの正断層型地震 の観測事実のすべてを説明することはできない，

\section{§ 3. ASSS (Along-strike Single Segmentation) 型超 巨大地震前後の広域で顕著な地震}

\section{$3.1 \quad 1960$ 年・2010 年チリ地震}

2004 年スマトラ地震のニコバル・アンダマン諸島に伸 展した地震と 1960 年 5 月 22 日・2010年 2 月 27 日チリ 地震（それぞれ， $M_{\mathrm{w}} 9.3 ， M_{\mathrm{w}} 8.8 ）$ は, 前者は沈み込み帯 が斜め沈み込み, 後者はほぼ垂直なプレート沈み込みの 地震带に発生した. 1960 年チリ地震は約 $200 \mathrm{~km} \times 800$ $\mathrm{km}$ の断層破壊 [Kanamori and Ciper (1974)], 2010 年は 約 $200 \mathrm{~km} \times 500 \mathrm{~km}$ [Hayes (2010)] である. ニコバル・ア ンダマン諸島周辺・チリ沖共に沈み込み帯の幅が狭く, 海溝から陸までの距離が $100 \mathrm{~km}$ にも満たない. Fig. 8 に示すように，2つのチリ地震発生前は地震空白域を形 成していて，顕著な地震活動は見当たらない [Kanamori (1981), Moreno et al. (2010)]. これらはすべて ASSS 型の
地震活動であることを示している [Koyama et al. (2012)] と考えられる。

1960 年チリ地震の余震に 1967 年 $M 7.3$ の地震（これ は震源位置・メカニズム解からアウターライズ正断層型 地震）がプロットされている。しかし，これは Engdahl and Villasenor (2002) によるマグニチュードの值で，そ の出典は不明と分類されている. Christensen and Ruff (1988) は, この地震を $M_{\mathrm{b}} 5.9$ としている. いずれにして もこの余震は $M_{\mathrm{w}} 7.5$ を超えるような顕著な地震ではな い. 1975 年 5 月 10 日 $M_{\mathrm{w}} 7.7$ は 1960 年の震源付近に発 生した II 型の余震である。2010 年マウレ地震では, 本 震発生当日 2 月 27 日に $M_{\mathrm{w}} 7.4$ の地震が発生した。これ はアウターライズの正断層型地震, I 型の余震である. しかしこれが最大余震か否かは, 地震発生からまだ時間 がたっていないから不明である. 次に大きいのは, 同年 3 月 11 日に発生した $M_{\mathrm{w}} 7.0$, これもアウターライズの正 断層型の地震である [USGS (2012)].

いずれにしても，ニコバル・アンダマン諸島，チリ海 溝沿いの ASSS 型の巨大地震では, 地震観測史上最大規 模と言われる 1960 年チリ地震でさえも，1975 年 5 月 10 日 $M_{\mathrm{w}} 7.7$ (II 型) をのぞき, $M_{\mathrm{w}} 7.5$ をこえるような顕著 な余震は震源域付近でも, アウターライズでも発生して いない.これはASSS 型の沈み込み帯で発生する超巨大 地震の最大余震では $M_{\mathrm{w}} 8$ をこえるような巨大地震が発 生していないことを示している。

\section{2 アリューシャン列島の地震}

アリューシャン列島はニコバル・アンダマン諸島と同 様に, 海洋プレートの沈み込みが場所場所により変化す る斜め沈み达みの地震带である。1957 年 3 月 9 日アン ドレアノフ島地震 $M_{\mathrm{w}} 8.6$ （古くは $M_{\mathrm{w}} 9.1 ）$ は余震域の拡 がりに不確定な要素が多いが, Lay et al. (1982) には断層 破壊が $100 \mathrm{~km} \times 900 \mathrm{~km}$ に及んだとある。いずれ細長い 断層であったことに違いはない.アリューシャン列島の 沈み达み带も海溝から島弧までの距離が $100 \mathrm{~km}$ 程度で その幅が狭い. Koyama et al. (2012) はこの 1957 年と 1965 年のアリューシャン列島ラット島での地震活動を ASSS 型と分類している. 1957 年の地震の目立った地震 活動は, 1964 年のアラスカ地震以前に発生した $M 7.0$ 〜 7.1の地震が 3 回である. これらの地震は本震の余震 域内で発生した。アウターライズに顕著な地震は発生し ていない，ただここでは，1986 年 5 月 7 日に $M_{\mathrm{w}} 7.9$, 1996 年 6 月 10 日に $M_{\mathrm{w}} 7.9$ の地震が発生している。これ ら二つの地震は, 低角の逆断層型の地震である [USGS (2012)]. これらは 1957 年の地震と同様のメカニズムで あり, 1957 年の余震域内で発生した部分的な断層面上で の繰り返し地震, あるいは II 型の地震活動と考えられ 


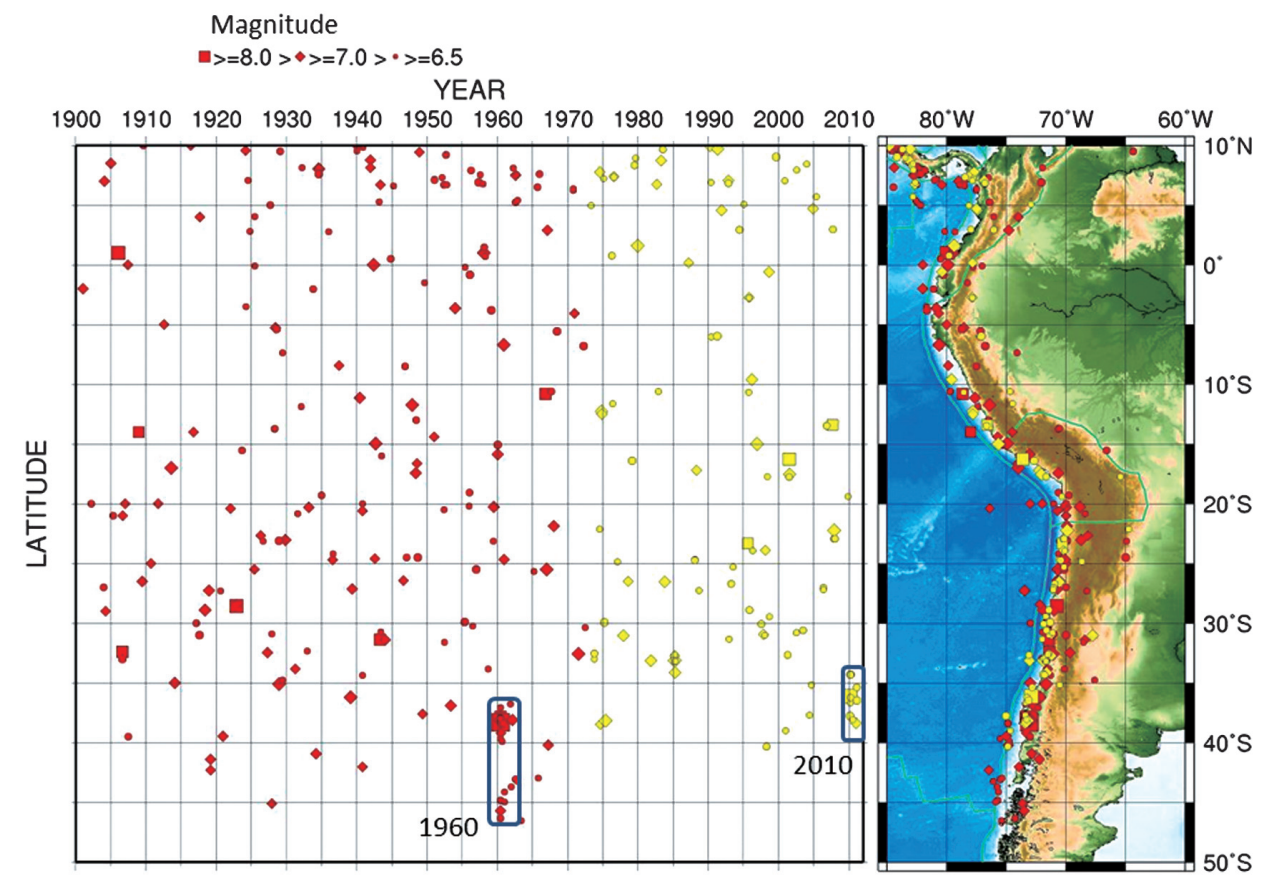

Fig. 8. Seismic activity along the Andean subduction zone. Sparse seismicity prior to the 1960 and 2010 great earthquakes (seismic gap) and the narrow subduction zone along the Chile trench are found, all of which are characteristic to the seismic activity in ASSS. Epicenters relocated by Engdahl et al. (1998) are used from 1900 to 1972. From 1973 to July, 2011 USGS NEIC database of <http://earthquake.usgs.gov/earthquakes/eqarchives/epic/epic_global. php is analyzed $>$.

る.

ASSS 型巨大地震の 1965 年 2 月 4 日ラット島地震 $M_{\mathrm{w}}$ 8.7 では，同年 3 月 30 日にアウターライズに正断層型の 地震 $M_{\mathrm{w}} 7.6$ が発生した [Abe (1972)]. USGS ではこの地 震を $M_{\mathrm{w}} 7.3$ としているが, I 型の地震活動と考えられ る.この地震は顕著な地震とする基準の $M_{\mathrm{w}} 7.5$ を超え ているようではあるが, 津波は小さく [Gusiakov (2001)], 大きな被害を発生しなかった。そのほか, ラット島地震 後の顕著な地震は, 1965 年の本震の震源域付近で 2003 年 11 月 17 日に $M_{\mathrm{w}} 7.8$ の地震が発生している。これは, 低角逆断層のメカニズムを示し, その震源位置からし て, 1965 年の余震域内で発生した部分的な繰り返し地 震，あるいはII 型の地震活動と考えられる。

このように見てくると, ASSS 型のアリューシャン列 島の超巨大地震では, $M_{\mathrm{w}} 8$ クラスの大きな余震は震源 域を拡大する領域でも, アウターライズ領域でも発生し ていないことがわかる. それは, チリ周辺の沈み込み带 でも同様であるが, ASSS 型の地震活動では海溝から陸 までの沈み込み帯にあるプレート境界の固着域が
ADDSのそれに比べて一様で, 地震発生時のアスペリ ティーとしてすべて破壊するからであろう[Hayes (2010), Moreno et al. (2010)]. ASSS 型の地震活動で顕著 なアウターライズの正断層型地震が少ないのは, プレー トの沈み込みが若く, プレート境界での固着を全体的に 断ち切るような大地震が発生しても, サブダクションプ ルが有効に働かないからなのだろう。もちろんこの地域 でも小さな規模の正断層地震は発生しており, その原因 はプレートの曲げが有効なのかもしれない [Stauder (1968), Christensen and Ruff (1988)].

\section{§4. 他のアウターライズ地震前後の地震活動}

視点を, アウターライズの正断層型地震 (M8 程度よ り大きい)に限ってみると, 1929 年アリューシャン諸島 地震 $M_{\mathrm{w}} 7.8,1933$ 年三陸はるか沖地震 $M_{\mathrm{w}} 8.4,1977$ 年ス ンバ島沖（インドネシア）地震 $M_{\mathrm{w}} 8.3,2007$ 年千島列島 東方沖地震 $M_{\mathrm{w}} 8.1$ と 2009 年サモア島沖地震 $M_{\mathrm{w}} 8.1$ が知 られている。これらの地震の詳しい議論は別の機会に譲 るが, I 型と分類した 1896-1933 年の地震活動は既に議 
Table 1. Megathrust earthquakes and accompanied significant earthquakes (larger than magnitude 7.5) with magnitude

\begin{tabular}{|c|c|c|c|c|c|c|c|}
\hline \multicolumn{2}{|c|}{ Year Megathrust } & \multirow{2}{*}{$\begin{array}{c}\mathrm{Mw} \\
8.8\end{array}$} & \multirow{2}{*}{$\begin{array}{c}\text { Segment } \\
\text { ADDS }\end{array}$} & \multirow{2}{*}{$\begin{array}{c}\begin{array}{c}\text { Outer-rise } \\
\text { (Type I) }\end{array} \\
---\end{array}$} & \multirow{2}{*}{$\begin{array}{c}\begin{array}{c}\text { Aftershock } \\
\text { (Type II) }^{b}\end{array} \\
19598.2\end{array}$} & \multirow{2}{*}{$\begin{array}{l}\text { Subduction }^{\mathrm{d}} \\
\text { Orthogonal }\end{array}$} & \multirow[t]{2}{*}{ Remarks $^{e}$} \\
\hline 1952 & Kamchatka & & & & & & \\
\hline \multirow[t]{2}{*}{1964} & Alaska & 9.2 & ADDS & 19877.9 & & Orthogonal & Strike slip/Normal \\
\hline & & & & & 20027.9 & Orthogonal & Denali /Strike slip \\
\hline \multirow[t]{2}{*}{2004} & Sumatra & 9.3 & ADDS - & 20128.6 & & Oblique & Strike slip/Normal \\
\hline & & & & & 20058.6 & & \\
\hline \multirow[t]{2}{*}{2011} & Tohoku & 9.0 & ADDS & (2011 7.5) & & Orthogonal & Normal fault \\
\hline & & & & & 20117.7 & & \\
\hline 1957 & Andreanof & 8.6 & ASSS & -- & 19867.9 & Oblique & \\
\hline 1960 & Chile & 9.5 & ASSS & --- & 19757.7 & Orthogonal & \\
\hline \multirow[t]{2}{*}{1965} & Rat Island & 8.7 & ASSS & 19657.6 & & Oblique & Normal fault \\
\hline & & & & & 20037.8 & & \\
\hline 2004 & Andaman ${ }^{c}$ & 9.3 & ASSS & (2009 7.5) & -- & Oblique & Normal fault \\
\hline 2010 & Chile & 8.8 & ASSS & (2010 7.4) & --- & Orthogonal & Normal fault \\
\hline
\end{tabular}

a: Type I indicates aftershocks occurred in the outer-rise or within subducting oceanic plate.

${ }^{b}$ : Type II indicates aftershocks events within aftershock area or in extending nearby area.

c: Seismic activity along the Sumatra trench and the Nicobar/Andaman islands shows distinct difference to be characterized as ADDS and ASSS.

${ }^{\mathrm{d}}$ : This indicates subduction type of oblique or orthogonal collision.

e: Remarks describe normal faulting, strike-slip with normal component, and Denali fault.

論した [Kanamori (1972)]. 2007 年千島列島東方沖地震 は，沈み込み带の逆断層型地震である 2006 年 11 月 15 日干島列島地震 $M_{\mathrm{w}} 8.3$ の余震と考えられ, これらは I 型 の地震活動と考えられる。特異なのは, 1929 年アリュー シャン地震, 1977 年スンバ島沖地震と 2009 年サモア地 震である.

Kanamori (1972) は 1896-1933 年の I 型の地震活動と は異なり, 1929 年アウターライズの正断層地震と 1946 年沈み込久带の津波地震の関連を指摘している。ここで は地震発生の順番が I 型とは逆なので便宜上 III 型の地 震活動と分類する. 2009 年サモアの正断層型地震もこ の地震に引き続き発生したプレート境界での地震を一連 の活動 [Lay et al. (2010)] として見れば III 型の活動であ る。 1977 年スンバ島沖地震は, 孤立したアウターライ ズの正断層型地震である [Spence (1986), Gusman et al. (2010)].これもプレート境界の地震が発生し, 1929 年 の地震と同様に将来 III 型の地震活動となるのかもしれ ない.しかし, スンダ海溝沿いでは, オーストラリアプ
レートのプレート間固着が弱く, 沈み込み帯に特有のプ レート間地震は少ない.したがって，スラブプルがこの アウターライズの正断層型地震の原動力と考えるとして も，スラブプルが働き固着が弱い沈み込むプレートの曲 げに大きく寄与していると考えることもできる [Spence (1986)].

\section{$\S 5 . \quad$ まめと議論}

ここでは, 超巨大地震前後の地震活動を, 個々の地震 セグメントや隣接する地震セグメント内での前震・本 震・余震としてや, 震源域の応力集中の緩和として, 狭 く考えるのではなく, 時間的・空間的に広域な場で誘発 された地震活動と考えて議論した。これは, 特段新しい 考えではなく, 例えば, Linde et al. (1994) は 1992 年 Landers 地震により $400 \mathrm{~km}$ も離れた地点での誘発され たマグマ活動を報告している，また，Mogi (1973) は日 本付近の大きな地震に先立ち顕著な深発地震が発生して いることを指摘している. 本論では多くの地震活動の羅 
列になっているように見えるが，我々が目指しているの はどの余震が最大であるかを判定することではなく，ど のような地震活動が ADDS/ASSS で特徵的に発生して いるかを知ることである。そのような知識の蓄積が超巨 大地震のメカニズムを知り, これからの地震活動を理解 するうえで重要と考えている。

Table 1 にここで取り扱った超巨大地震前後の顕著な 地震について ADDS/ASSS に分けてまとめた。まず気 が付くことは，被害の大きかった地震は存在するが，顕 著な大地震 $\left(M_{\mathrm{w}}>7.5\right)$ は超巨大地震に先だって起きては いないことである。ささらに, ASSS 型の超巨大地震では $M_{\mathrm{w}} 8$ をこえるような巨大な余震は, 震源域でもアウ ターライズでも起こっていないことである，それに引き かえ, ADDS 型の地震では, $M_{\mathrm{w}} 8$ をこえる巨大余震が震 源域十その周辺で発生している. アウターライズの正断 層成分を持つ地震に限っても, ADDS 型の超巨大地震で は, 1933 年型の沈み込むプレートが断ち切られるような 断層破壊と 2012 年型の沈み込むプルート内部での横ず れ断層があり, その規模も $M_{\mathrm{w}} 8$ を優に超える地震が発 生している。ただ，1952 年カムチャッカ地震のように， 顕著なアウターライズの地震が存在しない ADDS の領 域もあり, 単純にADDS 型の地震活動の特徵としてと か, サブダクションプルの働きとしてすべてを割り切れ ない点も残る。これはADDS/ASSS 地震活動の本質か ら発生する問題点かも知れない. 今後の問題点として重 要であると考えるから，あらためて指摘しておく.

プレート境界に発生する大きな地震の最大余震は, 余 震域内や余震域を拡張するような領域で発生する [宇津 (2001)）と考えられてきた。 しかし，ここで考えた超巨 大地震では, プレート境界に沿って大きな地震が発生し ている場合 (Type II) と, 沈み込むプレートのアウター ライズに正断層型の地震 (Type I) を誘発する場合があ ることを指摘した。これは，沈み込み帯がほぼ垂直か斜 め沈み込みであるかにはかかわらない傾向である.

さらに, 歴史上日本付近で発生した最大の地震である 1707 年宝永の地震では, 地震前に周辺地域での地震活動 は活発化したが, 顕著な被害地震はない. さらに, その 記録されている余震は, 本震の翌日の強い摇れと, 1708 年 2 月 13 日津波マグニチュード $m=1$ 程度の地震だけ である。歴史記録には, 1710 年 9 月 15 日いわき周辺で 発生した $M 6.5, m=0$ 程度の地震が記録されている[渡 辺 (1998)］から，それを上回る大きな余震は発生しな かったと考えられる。これは Fig. 1 で明らかなように, 南海トラフは ASSS 型の地震活動を示している地域で, 今まで述べてきた結論と整合的である.内陸の地震活動 に限っても，M7 前後の三河地震が 2 度（1686 年 $M 7 \pm$
1/4 と 1945 年 M 6.8）発生し地震被害を及ぼしている が, 顕著な内陸地震と言えるのは 1891 年濃尾地震 $M 8.0$ だけである，超巨大地震の前後を問わず，この濃尾地震 と 2002 年デナリ地震だけが歴史的に見て沈み込み帯の 近傍で発生した上盤の陸側プレート内で発生した $M \sim 8$ クラスの地震である。

我々は地震活動の様子から, ADDS/ASSS 型の地震七 グメントで異なるタイプのプレート間超巨大地震が発生 していると考えている. その考えに従い, 超巨大地震発 生前後での顕著な地震, 被害地震を見てきた. 起こるか もしれない次の地震の大きさの推定は地震セグメント, 地震空白域やドーナツパターン, GPS 観測などによるプ レート間固着域, 歴史的地震活動域などの拡がりに依存 して判断される. しかし, 超巨大地震の発生には, 大地 震規模の地震セグメントが連動して複数破壊することが 必要で, 破壊域が連動するメカニズムは理解が至ってい ない. また, 東北沖アウターライズでより大きな正断層 型の地震が今後発生するかもしれないが, それを知る観 測手段は現在なにもない.プレート間の巨大地震はプ レート間の強い固着が GPS 観測などから見い出される の対し，アウターライズの正断層型地震は, プレート間 の固着が弱く, スラブプルが働く場で発生するから, 普 通のプレート間巨大地震の周辺域での地殼変動とはまっ たく逆の現象が観測されるはずであることが予想され る.

もちろん, ここで述べた超巨大地震の発生場が唯一の 考え方であるとは限らない. また, Tanioka et al. (1997) が指摘しているように，三陸沖でも海溝軸に沿って多様 性に富んだ沈み込み带が存在している。このような多様 性はアラスカ・アリューシャンでも同様に指摘され [Freymueller et al. (2008)], 沈み込み帯に普遍的に存在す ることかもしれない [Kopp (2013)].

超巨大地震・連動型の断層破壊の発生メカニズムに は, 明確な理解はいまだ存在しない。東北沖プレート境 界に 1000 年にも及ぶひずみ蓄積が同地域で繰りかえさ れた津波地震の研究から指摘されている [Tsuzuki and Koyama (2013)]. しかし，それだけでは説明しきれない 超巨大地震が世界中で発生しているのも事実である。今 我々は, プレートが沈み込む方向の ADDS/ASSS と いった地震活動を強調したが, そのような単純な二元論 ばかりではなく, 横方向にも変化に富む沈み込み帯の理 解 [Hariri et al. (2013), Freymueller et al. (2008)] でも同 様に求められている。東北地方沖のアウターライズ地震 に限って言えば，スラブプルがその原動力となるのであ るから，プレート間の固着・非固着を陸上や海底の GPS 観測から監視することが重要であるし, 北海道沖の 
ADDS や南海トラフの ASSS を注視するのであれば，そ れに見合った観測の強化が必要とされる。それは我々の 仮説の検証という点からも，明確な視点であるが，地 震・津波防災上から，地震学が十分に考えなければいけ ないことである。

\section{謝辞}

北海道大学谷岡勇市郎氏に論文原稿を読んでいただき ました。また匿名の査読者のご意見は原稿を修正するう えで，大変参考になりました。編集委員の杉岡裕子氏に は原稿の不備，いたらぬ表現に多くのご助言をいただき ました，記して感謝いたします。この再々再校を投稿す るに当たり，その機会と時間を可能にしてくださった札 幌恵佑会病院の医師・看護師の皆様に心から感謝いたし ます。図面の作成に GMT [Wessel and Smith (1998)] と TSEIS [鶴岡弘, 東京大学地震研究所］を使用しました。

\section{文献}

Abe, K., 1972, Lithospheric normal faulting beneath the Aleutian trench, Phys. Earth Planet. Inter., 5, 190-198. 防災技術研究所, 2013, 地震調査研究推進本部政策委員 会第 57 回調査観測計画部会資料 計 57- (3) 日本海 溝海底地震津波観測網の整備一進渉状況—<http:// www.jishin.go.jp/main/seisaku/hokoku12h/k57-3.pdf $>$.

Christensen, D.H. and L.J. Ruff, 1988, Seismic coupling and outer rise earthquakes, J. Geophys. Res., 93, 1342113444.

Engdahl, E.R. and A. Villasenor, 2002, Global seismicity: 1900-1999, International Handbook of Earthquake Engineering Seismology, eds. W.H.K. Lee, H. Kanamori, P.C. Jennings and C. Kisslinger, 665-690.

Engdahl, E.R., R. van der Hilst, and R. Buland, 1998, Global teleseismic earthquake relocation with improved travel times and procedures for depth determination, Bull. Seism. Soc. Am., 88, 722-743.

Fowler, C.M.R., 2005, The Solid Earth, Second Edition, Cambridge University Press, New York, 77-88.

Freymueller, J.T., H. Woodard, S.C. Cohen, R. Cross, J. Elliot, C.F. Larson, S. Hreinsdottir, and C. Zweck, 2008, Active deformation process in Alaska, based on 15 years of GPS measurements, in Active Tectonics and Seismic Potential in Alaska, eds. J.T. Freymueller, P.T. Haeussler, R.L. Wesson, and G. Ekstrom, Geophysical Monograph Series, 179, AGU, Washington, D.C., 1-41.

Gusiakov, V.K., 2001, Proceedings, International Tsunami Symposium 2001, <http://tsun.sscc.ru/htdbpac/>.

Gusman, A.R., Y. Tanioka, T. Kobayashi, H. Latief, and W. Pandoe, 2010, Slip distribution of the 2007 Bengkulu earthquake inferred from tsunami waveforms and InSAR data, J. Geophys. Res., 115, B12316, doi:10.1029/ 2010JB007565.

Hariri, M.E., S.L. Bilek, H.R. DeShon, E.R. Engdahl, and S. Bisrat, 2013, Along-strike variability of rupture dura- tion in dubduction zone earthquakes, J. Geophys. Res., 118, 1-19, doi:10.1029/2012JB 009548.

羽鳥徳太郎, 2000, 三陸沖歴史津波の規模の再検討, 津 波工学研究報告, 17, 39-48.

Hayashi, Y., H. Tsushima, K. Hirata, K. Kimura, and K. Maeda, 2011, Tsunami source area of the 2011 off the Pacific coast of Tohoku Earthquake determined from tsunami arrival times at offshore observation stations, Earth Planets Space, 63, 809-813.

Hayes, G., 2010, Updated result of the Feb. 27, $2010 M_{\mathrm{w}}$ 8.8 Maule, Chile earthquake, <http://earthquake.usgs. gov/earthquakes/eqinthenews/2010/us2010tfan/finite_ fault.php $>$.

Heki, K., S. Miyazaki, and Y. Tamura, 1997, Silent fault slip following an interplate thrust earthquake at the Japan trench, Nature, 386, 595-597.

日野亮太, 2012, 海陸統合観測網の時代〜青写真と現実 ～，日本地震学会講演予稿集 2012 年度, S-05.

地震調査研究推進本部, 1988, 余震の確率評価手法につ いて, <http://www.jishin.go.jp/main/yoshin2/yoshin $2 . \mathrm{htm}>$.

Johnson, J.M. and K. Satake, 1999, Asperity distribution of the 1952 great Kamchatka earthquake and its relation to future earthquake potential in Kamchatka, Pure Appl. Geophys., 154, 541-553.

Kanamori, H., 1970, The Alaska earthquake of 1964: Radiation of long-period surface waves and source mechanism, J. Geophys. Res., 75, 5029-5040.

Kanamori, H., 1972, Mechanism of tsunami earthquakes, Phys. Earth Planet. Inter., 6, 346-359.

Kanamori, H., 1981, The nature of seismicity patterns before major earthquakes, Earthquake Prediction, an International Review, Maurice Ewing Series IV, eds. D.W. Simpson and P.G. Richards, AGU, Washington, D.C., 1-19.

Kanamori, H. and J.J. Cipar, 1974, Focal process of the great Chilean earthquake May 22, 1960, Phys. Earth Planet. Inter., 9, 128-136.

Kanamori, H., L. Rivera, and W.H.K. Lee, 2010, Historical seismograms for unraveling a mysterious earthquake: The 1907 Sumatra Earthquake, Geophys. J. Int., 183, 358-374, doi:10.1111/j.1365-246X.2010.0473.x.

Koketsu, K., Y. Yokota, N. Nishimura, Y. Yagi, S. Miyazaki, K. Satake, Y. Fujii, H. Miyake, S. Sakai, Y. Yamanaka, and T. Okada, 2011, A unified source model for the 2011 Tohoku earthquake, Earth Planet Sci. Lett., 310, 480-487.

国土地理院, 2012, 地震予知連絡会会報, 87, 国土地理 院, 580pp.

Koper, K.D., A.R. Hutko, T. Lay, C.J. Ammon, and H. Kanamori, 2012, Frequency-dependent rupture process of the $2011 M_{\mathrm{w}} 9.0$ Tohoku earthquake: Comparison of short-period $\mathrm{P}$ wave backprojection images and broadband seismic rupture models, Earth Planets Space, 63, 599-602.

Kopp, H., 2013, The control of subduction zone structural complexity and geometry on margin segmentation and 
seismicity, Tectonophysics, 589, 1-16.

Koyama, J., 1997, The complex faulting process of earthquakes, Kluwer Academic Pub., Amsterdam, 194pp.

小山順二・都筑基博, 2013, 日本付近の一重と二重の地 震セグメントで発生した地震が励起した津波, 北海道 大学地球物理研究報告, 76, 87-96.

小山順二・都筑基博 - 蓬田 清, 2012, 斜衝突帯の巨 大地震 (1) 相模卜ラフ, 北海道大学地球物理学研究報 告, 75, 161-174.

Koyama, J., K. Yoshizawa, K. Yomogida, and M. Tsuzuki, 2012, Variability of megathrust earthquakes in the world revealed by the 2011 Tohoku-oki earthquake, Earth Planets Space, 64, 1189-1198.

Lay, T., H. Kanamori, and L. Ruff, 1982, The asperity model and the nature of large subduction zone earthquakes, Earthq. Pred. Res., 1, 3-71.

Lay, T., H. Kanamori, C.J. Ammon, M. Nettles, S.N. Ward, R.C. Aster, S.L. Beck, S.L. Bilek, M.R. Brudzinski, R. Butler, H.R. DeShon, G. Ekstrom, K. Satake, and S. Sipkin, 2005, The great Sumatra-Andaman earthquake of 26 December 2004, Science, 308, 1127-1133.

Lay, T., C.J. Ammon, H. Kanamori, L.Rivera, K.D. Koper, and A.R. Hutko, 2010, The Samoa-Tonga great earthquake triggered doublet, Nature, 466, 964-968.

Lay, T., C.J. Ammon, H. Kanamori, M.J. Kim, and L. Xue, 2011, Outer trench-slope faulting and the $2011 M_{\mathrm{w}} 9.0$ off the Pacific coast of Tohoku earthquake, Earth Planets Space, 63, 713-718.

Linde, A.T., I.S. Sacks, M. Johnston, D. Hill, and R. Bilham, 1994, Increased pressure from rising bubbles as a mechanism for remotely triggered seismicity, Nature, 371, 408-410.

Mogi, K., 1969, Some features of recent seismic activity in and near Japan (2), Activity before and after great earthquakes, Bull. Earthq. Res. Inst., Univ. Tokyo, 47, 395-417.

Mogi, K., 1973, Relationship between shallow and deep seismicity in the western Pacific Region, Tectonophysics, 17, 1-22.

Moreno, M., M. Rosenau, and O. Oncken, 2010, 2010 Maule earthquake slip correlates with pre-seismic locking of Andean subduction zone, Nature, 467, 198-202.

行谷佑一 - 佐竹健治 - 山本 滋, 2010, 宮城県石巻 - 仙 台平野および福島県請戸川河口低地における 869 年貞 観津波のシミュレーション, 活断層・古地震研究報告, 10, 1-21.

岡村行信, 2012, 地質から東北地方太平洋沖地震を考え る，地震ジャーナル，54，1-12.

Obana, K., G. Fujie, T. Takahashi, Y. Yamamoto, Y. Nakamura, S. Kodaira, N. Takahashi, Y. Kaneda, and M. Shinohara, 2012, Normal-faulting earthquakes beneath the outer slope of the Japan trench after the 2011 Tohoku earthquake: Implication for the stress regime in the incoming Pacific plate, Geophys. Res. Let., 39, L00G24, doi: 10.1029/2011GL050399.

ポアンカレ, アンリ, 1959, 科学と仮説, 河野伊三郎訳,
岩波文庫, 288pp.

Royer, J.Y., 2012, When an oceanic tectonic plate cracks, Nature, 490, 183-185.

Ruff, L. and H. Kanamori, 1983, The rupture process and asperity distribution of three great earthquakes from long-period diffracted P-waves, Phys. Earth Planet. Inter., 31, 202-230.

Spence, W., 1986, The 1977 Sumba earthquake series: Evidence for slab pull force acting at a subduction zone, J. Geophys. Res., 91, 7225-7239.

Stauder, W.S.J., 1968, Tensional character of earthquake foci beneath the Aleutian trench with relation to sea floor spreading, J. Geophys. Res., 73, 7693-7701.

Stein, S. and E.A. Okal, 2007, Ultralong period seismic study of the December 2004 Indian ocean earthquake and implication for regional tectonics and the subduction process, Bull. Seism. Soc. Am., 97, S279-S295.

谷岡勇一郎・A. R. Gusman, 2012, 2011 年東北地方太平 洋沖地震による津波解析結果から再検討する巨大津波 の発生様式, 地震 2, 64, 265-270.

Tanioka, Y., L. Ruff, and K. Satake, 1997, What controls the lateral variation of large earthquake occurrence along the Japan trench, The Island Arc, 6, 261-66.

Tsuzuki, M. and J. Koyama, 2013, The 2011 Tohoku-oki megathrust earthquake $\left(M_{\mathrm{w}} 9.0\right)$ and slip deficit of the past tsunami earthquakes in the region, Fall Meeting, AGU, S43A-2458.

宇佐美龍夫 - 石井 寿 -今村隆正 - 武村雅之・松浦律子, 2013, 日本被害地震総覧 599-2012, 東京大学出版会, 東京, 694pp.

United States Geological Survey, 2012, < http://earthquake. usgs.gov/earthquakes/eqarchives/sopar/ $>$.

宇津徳治, 2001, 地震学, 第 3 版, 共立出版, 390pp.

Wang, K. and Y. Hu, 2006, Accretionary prisms in subduction earthquake cycles: The theory of dynamic Coulomb wedge, J. Geophys. Res., 111, B06410, doi:10. 1029/2005JB004094.

渡辺偉夫, 1998, 日本被害津波総覧第 2 版, 東京大学出 版会, 東京, 238pp.

Wessel, P. and W.H.F. Smith, 1998, New improved version of the Generic Mapping Tools released. EOS Trans. AGU, 79, 579.

Yagi, Y., T. Mikumo, J. Pacheco, and G. Reyes, 2004, Source rupture process of the Tecoman, Colima, Mexico earthquake of 22 January 2003, determined by joint inversion of teleseismic body-waves and nearsource data, Bull. Seism. Soc. Am., 94, 1795-1807.

Yomogida, K., K. Yoshizawa, J. Koyama, and M. Tsuzuki, 2011, Along-dip segmentation of the 2011 off the Pacific coast of Tohoku earthquake and comparison with other megathrust earthquakes, Earth Planets Space, 63, 697-701.

Yue, H., T. Lay, and K.D. Koper, 2012, En echelon and orthogonal fault ruptures of the 11 April 2012 great intraplate earthquakes, Nature, 490, 245-249. 